\title{
Coal Combustion By-product (CCB) Utilization in Turfgrass Sod Production
}

\author{
Maxim J. Schlossberg ${ }^{1}$ and William P. Miller \\ Department of Crop and Soil Sciences, University of Georgia, Miller Plant \\ Sciences Building, Athens, GA 30602-7272
}

Additional index words. Cynodon dactylon, Cynodon transvaalensis, hybrid bermudagrass, waste utilization, soil fertility, plant nutrients, land application

\begin{abstract}
Coal combustion by-products $(\mathrm{CCB})$ are produced nationwide, generating $10^{8}$ Mg of waste annually. Though varied, the majority of CCB are crystalline alumino-silicate minerals. Both disposal costs of CCB and interest in alternative horticultural/agricultural production systems have increased recently. Field studies assessed the benefit of CCB and organic waste/product mixtures as supplemental soil/growth media for production of hybrid bermudagrass [Cynodon dactylon (L.) Pers. $\times$ C. transvaalensis Burtt-Davy] sod. Growth media were applied at depths of 2 to $4 \mathrm{~cm}\left(200\right.$ to $\left.400 \mathrm{~m}^{3} \cdot \mathrm{ha}^{-1}\right)$ and vegetatively established by sprigging. Cultural practices typical of commercial methods were employed over 99- or 114-day growth periods. Sod was monitored during these propagation cycles, then harvested, evaluated, and installed offsite in a typical lawn-establishment method. Results showed mixtures of CCB and biosolids as growth media increased yield of biomass, with both media and tissue having greater nutrient content than the control media. Volumetric water content of CCB-containing media significantly exceeded that of control media and soil included with a purchased bermudagrass sod. Once installed, sod grown on CCB-media did not differ in rooting strength from control or purchased sod. When applied as described, physicochemical characteristics of CCB-media are favorable and pose little environmental risk to soil or water resources.
\end{abstract}

Turfgrass sod is an accompaniment of plants and soil that can be installed for rapid establishment and use. Turfgrass sod production, as a horticultural enterprise, requires fertile land, specialized equipment, and a sizable market for consumption. Sod production is a complex process requiring applied scientific and management skills (McCarty et al., 1999).

Turfgrass sod production is a common horticultural activity in the southeast United States. A combination of elevated housing starts and interest in row-crop alternatives has instigated a consistent expansion in sod production hectarage. Haydu and Cisar (1993) reported sod production in Florida grew from $1.4 \times 10^{4}$ to $3.5 \times 10^{4}$ ha between 1974 and 1987. Currently, most southeastern states have 5 to $9 \times 10^{3}$ ha in sod production, while Florida has near $4 \times 10^{4}$ ha.

Sod demand commonly mirrors regional housing starts. During periods of limited sod availability, a rapid production cycle optimizes profitability. For this reason, many researchers have investigated alternative production methods. Cisar and Snyder (1992) reported a method utilizing commercial compost spread

Received for publication 1 Nov. 2002. Accepted for publication 28 Apr. 2003. This paper represents partial fulfillment of the senior author's doctoral thesis requirement. Research conducted with grant funds provided by the Electric Power Research Institute, Palo Alto, Calif. The authors thank Gil Landry, Jr. and Lamar Larrimore for their technical assistance. Use of trade names does not imply endorsement of mentioned products.

${ }^{1}$ Doctoral Graduate. Current address: 116 ASI Bldg., University Park, PA 16802. E-mail address: mjs38@psu.edu over a plastic barrier and concluded the time required for sod production was significantly shortened when a complete fertilizer was applied biweekly. Following installation of both the experimental and commercially grown sod, the sod grown on compost possessed greater root weight and length.

Acceleration of the production cycle is one way to increase sod production profitability. Another method combines rapid propogation with societal waste reuse. A recent study examined zoysiagrass [Zoysia matrella (L.) and Z. japonica (Steud.)] sod production on soilless media (Ruemmele et al., 2001). In this greenhouse study, rice hulls, composted rice hulls, grass clippings, and a peat/vermiculite mixture were blanketed to a $1-\mathrm{cm}$ depth and sprigged. Results showed all alternative-media sod was produced in less time than conventionally grown field sod. Other studies have examined municipal compost and lime-stabilized biosolids as production media and report soil chemical relations (nutrient and/or salt imbalances) play a decisive role in the rate of sod establishment and maturity (Breslin, 1995). Coal combustion by-products (CCB) have been tested as soil amendments in centipedegrass [Eremochloa ophiuroides (Munro) Hack.] sod production (Adriano and Weber, 2001).

Coal is the fossil fuel used most widely in U.S. energy production. In 1998, annual U.S. production of fly ash (FA) and bottom ash (BA) totaled 60 and 10 million tons, respectively (Miller et al., 2000).

Characteristics of $\mathrm{CCB}$ are variable. Fly ash composition varies with coal source, combustion conditions, emission controls, and storage and handling. Some FA possess regulated metal concentrations that limit their use. However, many power generating plants create a FA product with an elemental composition similar to natural soils. Fly ash is used in structural fill and other engineering applications. For example, FA is commonly purchased for re-use in cement formulations (Okuda et al., 1997), but the majority of FA produced is impounded in lagoons or landfilled (Miller et al., 2000).

Bottom ash (BA) is a relatively coarse (0.05-3.0 mm diameter), inert material which is less dense than sand, minimizing shipping and handling weight of BA-containing consumer products. For this reason, BA is currently reused as an additive in cement block and structural fill applications (Miller et al., 2000). Current reuse of BA does not exceed production levels. Nationally, BA is purchased at lower costs than plant root media such as perlite, vermiculite, and sand (L. Larrimore, personal communication).

Investigations of bottom ash (BA) for use in container plant propagation have shown benefits (Bearce et al., 1997; Butler and Bearce, 1995; Wagner and Neal, 1984; Woodward et al., 1993). Bottom ash and other CCB have been successfully used to accelerate revegetation of disturbed landscapes. Bottom ash, when utilized as an aggregate for mine soil remediation, showed no adverse effect on ryegrass (Lolium sp.) yield, heavy metal uptake, or leachate composition (Sloan and Cawthon, 2001).

Nutrient deficiencies and suboptimal soil physical conditions have been corrected by CCB and/or FA application (Pathan et al., 2001). However, properly formulated blends of CCB and organic waste products more reliably provide primary nutrients needed to support agronomic crops (Sajwan et al., 1995). Mixing FA with biosolids can result in a soil amendment with favorable nutrient balance and handling properties (Schumann and Sumner, 1999).

Upland soils of the southern Piedmont are typically characterized by shallow A horizons and acidic $B$ horizons that restrict deep rooting and subsoil water extraction, and can necessitate frequent irrigations. Sod producers in this region have expressed interest in the use of low cost growth media as a soil surrogate that accelerates production rate and increases sod quality. Our first experimental objective was to evaluate the suitability of $\mathrm{CCB}$ and biosolid/compost mixtures as supplemental soil/growth media for accelerated generation of bermudagrass sod by typical commercial methods. The second experimental objective was to characterize the $\mathrm{N}$ content, organic matter content, water retentive properties, and post-installation visual quality and rooting strength of the experimental sod by comparison to control and commercially available sod.

\section{Materials and Methods}

Bottom ash (BA) and Class-F FA were provided by Georgia Power Inc. Compost was obtained from the Athens Clarke County municipal subcontractor (Classic City Composting, Athens, Ga.), and anaerobically digested 
sewage sludge (SS) obtained from a municipal wastewater treatment plant (Athens, Ga.).

Preliminary greenhouse tests of mixtures containing various ratios of $\mathrm{BA}, \mathrm{FA}$, compost, and biosolid were conducted prior to field preparation. On the basis of the greenhouse results, three experimental mixtures were chosen for testing in the Year 1 field study. These three experimental growth media mixes (treatments) were formulated on a volume basis: 2 parts BA : 1 part municipal compost $(\mathrm{CP}), 2 \mathrm{BA}+1 \mathrm{CP}$; 1 part $\mathrm{BA}$ : 1 part $\mathrm{CP}, 1 \mathrm{BA}+1 \mathrm{CP}$; and 4 parts BA : 1 part FA : 1 part sewage sludge (SS), 4BA+1FA+1SS. The control growth media consisted of 2 parts fine sand mixed with 1 part municipal compost (2 Sand :1 CP). Mix chemical properties are described in Table 1. Specific procedures used to characterize growth media components are detailed in Schlossberg et al. (2004).

Year 1 (2000) growing procedures. The sod production field experiment was initiated in May 2000. Mixes were uniformly spread to depths of 2,3 , or $4 \mathrm{~cm}(200,300$, $400 \mathrm{~m}^{3} \cdot \mathrm{ha}^{-1}$ ) over a compacted subsoil of the Cecil series (clayey, kaolinitic, thermic, typic Kanhapludults). The field site received full sun throughout the summer and was equipped with an automated, potable-water, overhead irrigation system. Once applied, the experimental growth media were not tilled into the soil. The sod production field was irrigated with $3 \mathrm{~cm}$ water on 2 and 6 June to purge salts present in the root zone.

Mature 'TifSport' bermudagrass sod [Cynodon dactylon $(\mathrm{L}$.) Pers. $\times$ C. transvaalensis Burtt-Davy], formerly 'Tift 94' (Hanna et al., 1997), was obtained from a foundation-stock field at the Georgia Crop Improvement Association, Athens. Bermudagrass sod was washed free of soil and pulverized into vegetative sprigs. The $48-\mathrm{m}^{2}$ experimental site was established with viable moist sprigs at $60 \mathrm{~kg} \cdot \mathrm{ha}^{-1}$ on 8 June 2000. A broadcast application of fertilizer (Gold Kist Starter and triple super phosphate) provided $12.2,48.8$, and $10.1 \mathrm{~kg} \cdot \mathrm{ha}^{-1}$ of actual $\mathrm{N}$, $\mathrm{P}$, and $\mathrm{K}$, respectively, on 9 June, $1 \mathrm{~d}$ after planting (DAP). The experimental sod field was rolled with a water ballast drum every $10 \mathrm{~d}$ until the first mowing. A loose-weave outdoor-type polymer tarp $\left(8 \times 8 \mathrm{~m}^{2}\right)$ was used to protect the field from inclement weather until vegetative cover reached $50 \%$ of the field area.

Beginning 36 DAP, the field was mowed every 3 to $4 \mathrm{~d}$ with a motorized reel-mower at a height of $3 \mathrm{~cm}$ and irrigated equally to prevent wilt. Leaf clippings from the fifth mowing (55 DAP) were collected, triple-rinsed with DI $\mathrm{H}_{2} \mathrm{O}$, and measured for $\mathrm{N}$ content (Nelson and Sommers, 1996). Every $8 \mathrm{~d}$, until $11 \mathrm{~d}$ before sod harvest (88 DAP), leaf clippings were collected across application volumes in each block, pooled, and sampled for $\mathrm{N}$ analysis. Supplemental N fertilizer sprays $\left(24.5 \mathrm{~kg} \cdot \mathrm{ha}^{-1}\right.$ as $\mathrm{NH}_{4} \mathrm{NO}_{3}$ ) were immediately applied to all plots of a specific growth media type when average leaf clipping $\mathrm{N}$ concentration fell below $80 \%$ of a well-fertilized bermudagrass reference (maintained on-site), every 8 d. Additional plant tissue was harvested 72 DAP, triple-rinsed with DI water, and nitric

Table 1. Physicochemical properties of amendment materials and growth media formulations used in sod field experiments.

\begin{tabular}{llllllllll}
\hline Mixture Components & $\mathrm{N}$ & $\mathrm{P}$ & $\mathrm{K}$ & $\mathrm{Ca}$ & $\mathrm{Mg}$ & $\mathrm{Cu}$ & $\mathrm{Zn}$ & $\mathrm{pH}_{\mathrm{H}_{2} \mathrm{O}}{ }^{2}$ & $\mathrm{EC}$ \\
\hline & $---\mathrm{mg}^{-1}$
\end{tabular}

Fly ash (FA)

Bottom ash (BA)

Athens sewage sludge (SS)

Athens compost (CP)

$\begin{array}{rrr}<1 & 1 & 17 \\ <1 & <1 & <1 \\ 33 & 23 & 2 \\ 10 & 11 & 2\end{array}$

$\begin{array}{rr}16 & Y e a r \\ 1 & \\ 16 & \\ 7 & \end{array}$

6
$<1$
2
1

$\begin{array}{rrrr}20 & 49 & 11.6 & 1.2 \\ 13 & 71 & 6.4 & 0.1 \\ 270 & 867 & 7.2 & 6.3 \\ 127 & 536 & 4.6 & 5.2\end{array}$

Volumetrically formulated experimental mixes

\begin{tabular}{lllr}
\hline Control $(2 \text { Sand : } 1 \mathrm{CP})^{y}$ & $1^{\mathrm{x}}$ & 1 & $<1$ \\
$1 \mathrm{BA}+1 \mathrm{CP}$ & 3 & 4 & 1 \\
$2 \mathrm{BA}+1 \mathrm{CP}$ & 2 & 2 & $<1$ \\
$4 \mathrm{BA}+1 \mathrm{FA}+1 \mathrm{SS}$ & 5 & 3 & $<1$
\end{tabular}

$\begin{array}{rrrrrr}1 & <1 & 17 & 70 & 5.2 & 0.6 \\ 2 & <1 & 52 & 231 & 5.2 & 2.2 \\ 1 & <1 & 36 & 167 & 5.3 & 1.6 \\ 2 & <1 & 52 & 188 & 7.2 & 0.8\end{array}$

Fly ash (FA)

Bottom ash (BA)

Athens sewage sludge (SS)

Athens compost (CP)

Year 2

$\begin{array}{rrrr}77 & 81 & 9.8 & 1.4 \\ 39 & 76 & 5.9 & 0.1 \\ 293 & 941 & 7.1 & 6.3 \\ 140 & 390 & 5.2 & 2.3\end{array}$

Volumetrically formulated experimental mixes

\begin{tabular}{|c|c|c|c|c|c|c|c|c|c|}
\hline Control (1 Sand : 2CP) & 5 & 2 & 1 & 4 & $<1$ & 62 & 171 & 5.8 & 0.9 \\
\hline $1 \mathrm{BA}+2 \mathrm{CP}$ & 7 & 3 & 1 & 4 & 1 & 78 & 216 & 5.9 & 1.9 \\
\hline $3 \mathrm{BA}+1 \mathrm{FA}+1 \mathrm{SS}$ & 13 & 4 & $<1$ & 3 & $<1$ & 92 & 233 & 6.9 & 2.5 \\
\hline $4 \mathrm{BA}+1 \mathrm{FA}+1 \mathrm{SS}$ & 11 & 3 & $<1$ & 2 & $<1$ & 83 & 206 & 6.7 & 1.2 \\
\hline $2 \mathrm{BA}+1 \mathrm{FA}+1 \mathrm{SS}+1 \mathrm{CP}$ & 16 & 5 & 1 & 4 & 1 & 111 & 291 & 6.7 & 2.5 \\
\hline
\end{tabular}

${ }^{2}$ Water-pH $\left(\mathrm{pH}_{\mathrm{H}_{2} \mathrm{O}}\right)$ and electrical conductivity (EC), measured on fresh formulations of mixes.

${ }^{\mathrm{y}} \mathrm{FA}=$ Fly ash; $\mathrm{BA}=$ Bottom ash; $\mathrm{SS}=$ Athens anerobically digested sewage sludge; $\mathrm{CP}=$ Athens municipal compost.

${ }^{\mathrm{x}}$ Nutrient concentration of mixes were calculated empirically.

acid digested for plant nutrient concentration (Jones, 1991)

Elemental composition of all plant tissue was analysed using ICP-MS. Following the 99-d maturation period, bermudagrass sod was harvested with a self-powered, walk-behind sod harvester (Ryan Sod Cutter [45.7-cm width], Textron Golf,Augusta, Ga.). Sod grown on varying growth media volumes were all harvested at their corresponding depths, e.g., sod grown on the 4-cm application media volume were cut to include $\approx 3 \mathrm{~cm}$ of the growth media. Three days following, $1.3 \mathrm{~m}^{2}$ of sod grown on each type of media at each application volume (11.7- $\mathrm{m}^{2}$ total) were installed both conventionally and on high-strength steel grids on a maintained turfgrass area at the Georgia Agricultural Experiment Station, Griffin. Remaining bermudagrass at the sod production site was treated with label rates of glyphosate on 19 and 29 Sept. 2000.

Year 2 (2001) growing procedures. A second sod production field study was conducted in 2001 to retest the $4 \mathrm{BA}+1 \mathrm{FA}+1 \mathrm{SS}$ growth media mixture and newly formulated variations of Year 1 growth media mixtures. The second year experimental mixtures were formulated on a volume basis as follows: 1 part $\mathrm{BA}$ to 2 parts $\mathrm{CP}, 1 \mathrm{BA}+2 \mathrm{CP} ; 2$ parts $\mathrm{BA}$ to 1 part FA to 1 part sewage sludge (SS) : 1 part $\mathrm{CP}, 2 \mathrm{BA}+1 \mathrm{FA}+1 \mathrm{SS}+1 \mathrm{CP}$; 4 parts $\mathrm{BA}: 1$ part FA : 1 part SS, 4BA+1FA+1SS; and 3 parts BA : 1 part FA : 1 part SS, 3BA+1FA+1SS. The control growth media consisted of 1 part sand mixed with 2 parts municipal compost, 1 Sand:2CP. Mix physicochemical properties are described in Table 1.

The sod production field experiment was initiated in May 2001. The surface of the Cecil soil site used in Year 1 was stripped to a depth of $2 \mathrm{~cm}$ and compacted. Mixes were uniformly spread to a depth of $4 \mathrm{~cm}\left(400 \mathrm{~m}^{3} \cdot \mathrm{ha}^{-1}\right)$. Three cenitmeters of irrigation was applied to the sod field on 10 and 16 May.

Mature 'TifSport' bermudagrass sod was obtained from the Year 1 source in early May 2001. On 20 May 2001, the $48 \mathrm{~m}^{2}$ of experimental growth media were established with viable moist sprigs at $60 \mathrm{~kg} \cdot \mathrm{ha}^{-1}$. A broadcast application of commercial fertilizer provided $48.8,48.8$, and $40.5 \mathrm{~kg} \cdot \mathrm{ha}^{-1}$ of actual N, P, and $\mathrm{K}$, respectively, on 4 June, $14 \mathrm{~d}$ after planting (DAP). The loose-weave tarp and drum roller were used as described previously. Once $>50 \%$ of the field area was visibly bermudagrass ( 58 DAP), it was mowed and cultured as described in Year 1. Leaf clippings from the third mowing (67 DAP) were measured for $\mathrm{N}$ content and this procedure was repeated until $14 \mathrm{~d}$ prior to harvest (100 DAP). Supplemental N fertilizer sprays were applied 1 to $3 \mathrm{~d}$ later to all plots of a specific growth medium type when average leaf clipping N concentration fell below $90 \%$ of the treatment mix having the greatest observed $\mathrm{N}$ concentration. Leaf clippings harvested at the third mowing (67 DAP), 85 DAP, and $3 \mathrm{~d}$ before harvest (111 DAP) were triple-rinsed with DI water, and nitric acid digested for nutrient concentrations.

Two cores of sod/growth media were harvested with 7.3-cm-diameter steel rings from each replicated plot at 84 DAP. Following the 114-d maturation period, bermudagrass sod was harvested identically to Year 1 procedures. The following day, $3.3 \mathrm{~m}^{2}$ of sod grown on each type of media $\left(16.7-\mathrm{m}^{2}\right.$ total) was installed both conventionally and on high-strength steel grids on a maintained turfgrass area at the Georgia Agricultural Experiment Station. Additionally, $2.5 \mathrm{~m}^{2}$ of certified 'TifSport' bermudagrass sod was purchased from a retail outlet (Ward's Super Sod, Bogart, Ga.) and transported to the 
Georgia Agricultural Experiment Station as a comparative sod product in the randomized complete-block design.

Year 1 and Year 2 postproduction analysis. Harvested sod (bermudagrass and growth media) remaining at the production field was collected and destructively analyzed for sod biomass, organic matter content, $\mathrm{pH}, \mathrm{EC}$, and total N content (Ben-Dor and Banin, 1989; Nelson and Sommers, 1996; Rhoades, 1996; Thomas, 1996). In Year 1, growth media removed from only the 4-cm application height plots were separated from shoot biomass and air-dried for analysis. Soil water retention was measured using pressure plates (Soil Moisture Equipment Co., Santa Barbara, Calif.) (Klute, 1986). Growth media samples were tightly packed into steel cores of 2-cm radius and $0.9-\mathrm{cm}$ height and saturated with $0.01 \mathrm{M}$ $\mathrm{CaCl}_{2}$ solution at atmospheric pressure. Four replications of every treatment were simultaneously measured at each level of matric potential $(2,6,10,80,250$, and $1450 \mathrm{kPa})$. Plant-available soil water was calculated by subtracting volumetric water remaining at 1450 $\mathrm{kPa}$ tension from volumetric water at $10 \mathrm{kPa}$. Bulk density measurements were made on the oven-dried media.

Sod biomass, referring to shoots and roots present in a given volume of sod, were collected in duplicate subsamples on 12 Aug. 2001 (84 DAP) and triplicate subsamples on 15 Sept. 2000 (99 DAP) and 11 Sept. 2001 (114 DAP) and oven-dried $\left(95^{\circ} \mathrm{C}\right)$ before weighing. Sod dry weight was calculated from the sum of the media bulk density value and dry biomass at harvest (on an area basis). Retained gravimetric water ( $>80 \mathrm{kPa}$ tensions) and dry weight of the finished sod was summed to formulate total sod pallet weight.

On 10 Apr. 2001, the Year 1 sod was rated for visual quality, and high-strength steel grids were located, edged, and detached from soil using a specially designed tripod and electric winch. A load sensor (MSI-7200 Dyna-Link Tension/Load Sensor, Measurement Systems, Seattle) measured required force of sod detachment, a direct measure of sod rooting strength (King and Beard, 1969). Following installation of Year 2 sod, a soil compaction/wear simulator made a 30-pass split-plot treatment to the experimental units (Nov. 2001). The self-propelled soil compaction/wear simulator applies a static pressure of $0.5 \mathrm{~kg} \cdot \mathrm{cm}^{-2}$ over a treatment width of $76 \mathrm{~cm}$ (Carrow et al., 2001b). On 22 Apr. 2002, visual quality and required force of detachment were measured on the Year 2 sod.

Experimental design. In Year 1, data of the sod production (biomass) and installation (rooting strength and visual quality) components were analyzed as strip-plot configurations. Growth media analyses were performed on samples collected only from the 4-cm (400 $\mathrm{m}^{3} \cdot \mathrm{ha}^{-1}$ ) plots. Leaf clippings were collected across application heights and pooled for analysis. Therefore, growth media physicochemical characteristics and leaf clipping elemental status were analyzed as randomized completeblock designs (RCBD). In Year 2, experimental design for the sod production component was a
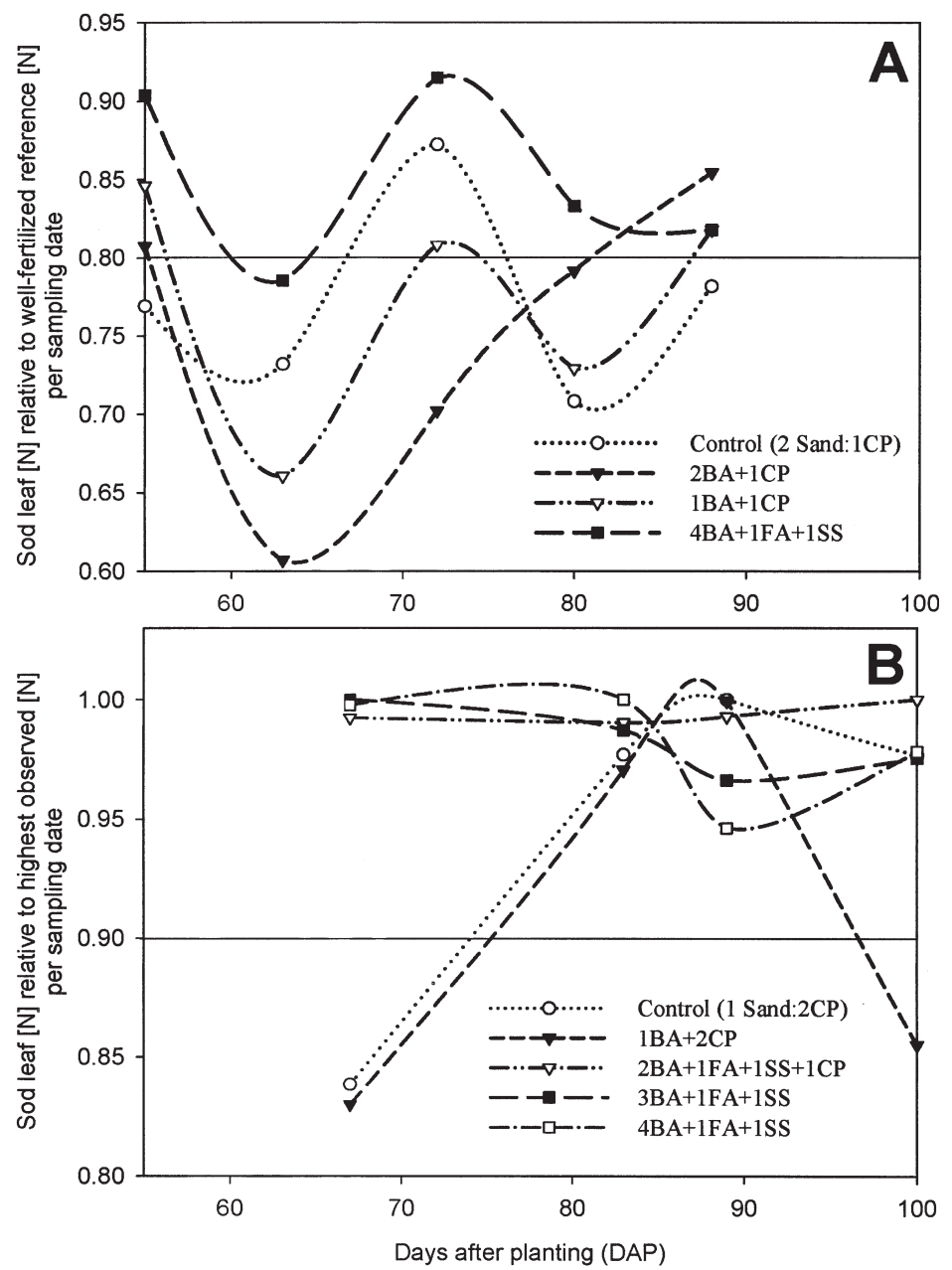

Fig. 1. Relative $\mathrm{N}$ concentration in bermudagrass leaves by growth media and days after planting in (A) Year 1, and (B) Year 2. Growth media were comprised of bottom ash (BA), fly ash (FA), anaerobic digested biosolids (SS), and/or municipal compost (CP), in the volumetric ratios indicated. Solid horizontal lines indicate leaf $\mathrm{N}$ sufficiency, observations recorded below prompted immediate $\mathrm{N}$ fertilization at a $24.5 \mathrm{~kg} \cdot \mathrm{ha}^{-1}$ rate.

RCBD. Sod biomass and leaf tissue elemental composition measurements taken on multiple dates in Year 2 were analyzed as repeated measures (split-plots) in time. The experimental design for the installation component (rooting strength and visual quality) was a RCBD with a wear/compaction split-plot treatment. The PROC GLM subroutine of SAS (Version 8.2, SAS Institute, Cary, N.C.) facilitated analysis of all data. Predetermined multiple comparisons of treatments within significant $(P \leq 0.050)$ main or interactive effects were conducted using Tukey's Studentized Range procedure.

\section{Results and Discussion}

Year 1 establishment/propagation period. Mowing procedures did not commence until $50 \%$ of the sod field was covered with vegetation. This occurred 36 DAP in Year 1. Under irrigated, full sun, and optimal-temperature conditions, bermudagrass vigor is often directly related to $\mathrm{N}$ sufficiency. In the first 2 months of production, leaf tissue $\mathrm{N}$ was maintained at sufficient levels (all leaf clippings collected 55 DAP contained $>37 \mathrm{~g} \cdot \mathrm{kg}^{-1}$ $\mathrm{N}$ by dry mass). In the remaining 6 weeks of production, deficiency of leaf tissue $\mathrm{N}$ in sod propagated on media containing biosolid and FA was observed only once (4BA+1FA+1SS; $63 \mathrm{DAP})$. The sod grown on the control media required four fertilizations over the same period (55-88 DAP), as shown in Figure 1a. Municipal compost in this experiment was originally formulated from 1 part yard waste : 2 parts biosolids (by volume) and possessed a C:N ratio of 14:1. Organic $\mathrm{N}$ contained in the biosolid/FA mixture was greater than levels present in the compost by mass. Supplemental $\mathrm{N}$ fertilizer applications to the control sod totalled $\mathrm{N}$ at $98 \mathrm{~kg} \cdot \mathrm{ha}^{-1}$. The $1 \mathrm{BA}+1 \mathrm{CP}$ and $2 \mathrm{BA}+1 \mathrm{CP}$ growth media sod required $\mathrm{N}$ at 49 and $73.5 \mathrm{~kg} \cdot \mathrm{ha}^{-1}$ over the same period. Land application of young biosolid material has resulted in greater mineral $\mathrm{N}$ release than mature compost derived from young biosolids (Castellanos and Pratt, 1981).

Primary and other macronutrient content of sod leaf clippings at 72 DAP were generally sufficient (Table 2). Although significant differences between treatment mixes were observed for primary and macronutrients, concentrations of $\mathrm{P}, \mathrm{K}, \mathrm{Ca}, \mathrm{Mg}, \mathrm{Cu}$, and $\mathrm{Zn}$ were all within established nutrient sufficiency ranges common for turfgrasses (Carrow et al., 2001a). 
These results indicate nutrient availability was not a limiting growth factor. Conversely, the level of fertility likely contributed to accelerated growth in the establishment period. Initial establishment was complete at 99 DAP, $25 \%$ to $50 \%$ of the time normally required for bermudagrass in traditional sod production systems (McCarty et al., 1999).

Year 1 postharvest. In Year 1, both mixture composition and application volume significantly affected sod biomass. The 4-cm depth (all mixtures averaged) resulted in significantly greater biomass than the 3- and 2-cm application depths ( $36 \%$ to $58 \%$, respectively). The nutrient rich and physically favorable growth media fostered bermudagrass vigor in direct relation to application volume (Table 3 ). Multiple comparison tests showed the 4BA+1FA+1SS media supported development of significantly greater sod biomass (24\% to $40 \%)$ than the other growth media, for all application volumes combined. Soil chemical reaction/properties of all growth media were favorable for plant growth (Table 4). This significant treatment effect on biomass production (4BA+1FA+1SS) likely resulted from improved physical and/or inherent chemical properties of the mixture, such as its mineralizable nutrient content. Warm-season turfgrass sod establishment and biomass production are accelerated by increasing $\mathrm{N}$ fertilization rate (Ruemmele et al., 2001). Phosphorous uptake from the 4BA+1FA+1SS mixture was $19 \%$ to $32 \%$ greater than the other treatment mixes (Table 2). Leaf tissue of sod grown on the 4BA+1FA+1SS media possessed a nearly constant $\mathrm{N}$ concentration throughout the entire grow-in (Fig. 1). Wong et al. (1998) showed sewage sludge additions ( $0.3 \%$ to $3.5 \%$ by mass) to a sandy soil resulted in elevated $\mathrm{NH}_{4}{ }^{+}$concentrations as long as 70 $\mathrm{d}$ after application.

Nitrogen mineralization from compost is also well substantiated. In a recent growth chamber study, soil $\mathrm{N}$ from biosolid compost accounted for $33 \%$ of $\mathrm{N}$ requirements in tall fescue [Festuca arundinacea (Schreb.)] culture (Sikora and Enkiri, 1999). Timely application of water-soluble $\mathrm{N}$ fertilizer to the other treatment mixes did not result in biomass production equivalent to sod grown in the 4BA+1SS+1FA mixture, other characteristics of the 4BA+1SS+1FA mixture may have influenced bermudagrass vigor.

Following sod harvest, laboratory tests of the experimental sod mixtures revealed significantly different values of bulk density and soil water availability (Table 4). Due to the high rate of composted organic matter inclusion and its inherent low mass, bulk densities of experimental sod growth mixes were low. Bulk density of all mixtures increased over the production cycle (data not shown). Plant available water in soil/sod is highly desirable during periods of measurable evapotranspiration. The portion of capillary water designated as plant available is directly related to sod quality (even survivability) under drought conditions. Volumetric plant available water $\left(\mathrm{PAW}_{\mathrm{v}}\right)$ in the media tended to increase with organic matter content by weight, with the exception of the 4BA+1SS+1FA mixture

Table 2. Nutrient concentration of bermudagrass leaf clippings by growth media mix (Year 1) and growth media mix and days after planting (DAP) (Year 2).

\begin{tabular}{|c|c|c|c|c|c|c|c|}
\hline \multirow[b]{2}{*}{ Growth media mixes } & \multicolumn{6}{|c|}{ Year 1 growing season ${ }^{2}$} & \multirow[b]{2}{*}{$\mathrm{Zn}$} \\
\hline & $\mathrm{N}$ & $\mathrm{P}$ & $\mathrm{K}$ & $\mathrm{Ca}$ & $\mathrm{Mg}$ & $\mathrm{Cu}$ & \\
\hline & \multicolumn{5}{|c|}{ 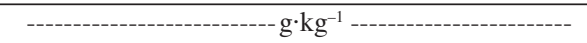 } & \multicolumn{2}{|c|}{$----\mathrm{mg} \cdot \mathrm{kg}^{-1}--$} \\
\hline Control (2 Sand : $\left.1 \mathrm{CP}^{\mathrm{y}}\right)$ & $40.5 \mathrm{ab}$ & $3.7 \mathrm{~b}^{\mathrm{x}}$ & $28.2 \mathrm{~b}$ & $4.7 \mathrm{~b}$ & $1.6 \mathrm{~b}$ & 8 & 34 \\
\hline $1 \mathrm{BA}+1 \mathrm{CP}$ & $37.6 \mathrm{~b}$ & $4.0 \mathrm{~b}$ & $30.4 \mathrm{~b}$ & $5.3 \mathrm{~b}$ & $1.7 \mathrm{~b}$ & 9 & 39 \\
\hline $2 \mathrm{BA}+1 \mathrm{CP}$ & $33.4 \mathrm{c}$ & $4.1 \mathrm{~b}$ & $31.6 \mathrm{ab}$ & $5.5 \mathrm{~b}$ & $1.8 \mathrm{~b}$ & 8 & 37 \\
\hline $4 \mathrm{BA}+1 \mathrm{FA}+1 \mathrm{SS}$ & $42.8 \mathrm{a}$ & $4.9 \mathrm{a}$ & $34.4 \mathrm{a}$ & $8.1 \mathrm{a}$ & $2.5 \mathrm{a}$ & 7 & 39 \\
\hline Source of variation & \multicolumn{7}{|c|}{ ANOVA } \\
\hline Mix & *** & ** & * & ** & $*$ & NS & N \\
\hline
\end{tabular}

Growth media mixes

Control (1 Sand : 2CP)

$1 \mathrm{BA}+2 \mathrm{CP}$

$3 \mathrm{BA}+1 \mathrm{FA}+1 \mathrm{SS}$

$4 \mathrm{BA}+1 \mathrm{FA}+1 \mathrm{SS}$

$2 \mathrm{BA}+1 \mathrm{FA}+1 \mathrm{SS}+1 \mathrm{CP}$

Avg of all mixes

Control (1 Sand : 2CP)

$1 \mathrm{BA}+2 \mathrm{CP}$

$3 \mathrm{BA}+1 \mathrm{FA}+1 \mathrm{SS}$

$4 \mathrm{BA}+1 \mathrm{FA}+1 \mathrm{SS}$

$2 \mathrm{BA}+1 \mathrm{FA}+1 \mathrm{SS}+1 \mathrm{CP}$

Avg of all mixes

Control (1 Sand : 2CP)

$1 \mathrm{BA}+2 \mathrm{CP}$

$3 \mathrm{BA}+1 \mathrm{FA}+1 \mathrm{SS}$

$4 \mathrm{BA}+1 \mathrm{FA}+1 \mathrm{SS}$

$2 \mathrm{BA}+1 \mathrm{FA}+1 \mathrm{SS}+1 \mathrm{CP}$

Avg of all mixes

Avg of all mixes, all dates

Source of variation

\begin{tabular}{|c|c|c|c|c|c|c|c|}
\hline & & & & & & & \\
\hline Mix & $* *$ & * & NS & NS & $*$ & NS & NS \\
\hline DAP & $* * *$ & $* * *$ & NS & NS & $* * *$ & NS & $* *$ \\
\hline Mix $\times$ DAP & $* * *$ & $* * *$ & NS & $* * *$ & NS & $* *$ & NS \\
\hline
\end{tabular}

${ }^{2}$ Leaf tissue harvested for primary and macronutrient content $72 \mathrm{~d}$ after planting (DAP).

${ }^{\mathrm{y}} \mathrm{BA}=$ bottom ash; $\mathrm{CP}=$ municipal compost; $\mathrm{FA}=$ fly ash; $\mathrm{SS}=$ anaerobic-digested sewage sludge.

${ }^{x}$ Within each year (or DAP), means followed by a different lowercase letter denotes significant difference by mix, according to Tukey's Studentized Range $(\alpha=0.05)$.

"For Year 2, within columns, means followed by a different uppercase letter denotes significant difference by DAP, according to Tukey's Studentized Range $(\alpha=0.05)$.

${ }^{* * * * * * * *}$ Significant at $P \leq 0.05,0.01$, and 0.001 , respectively.

(Table 4). Two reasons for this exception are possible. First, is the presence of FA. Fly ash is mainly comprised of particles $2-50 \mu \mathrm{m}$ in diameter. Inclusion of silt-sized particles in a coarser-textured soil has been shown to increase capillary porosity. Campbell et al. (1983), showed plant-available gravimetric water (matric potentials between 10-1500 $\mathrm{kPa}$ ) of a coarse sand to increase from 0.01 to $0.09 \mathrm{~g} \cdot \mathrm{g}^{-1}$ with the addition of $20 \%$ fly ash by mass. The second contributor may be the undecomposed biosolids. Coarse-textured soils receiving manure additions showed increased water holding capacity relative to untreated soils (Tester, 1990). Although the production field plots were irrigated regularly to prevent wilt, increased soil water availability may have contributed to enhanced biomass production (Table 3).

Seven months following installation (April), no significant differences in rooting strength or visual quality were measured among treatment mixes or application heights (data not shown). Ammonification of organic $\mathrm{N}$ from the total $\mathrm{N}$ reserves may have been suppressed by low temperatures preceding visual ratings. Visual shoot quality was generally acceptable and quality differences among growth media types were not observed (data not shown).

Year 2 establishment/propagation period. Formulations of the experimental CCBPmixes used in the second year growing season were generally based on Year 1 results. Although organic $\mathrm{N}$ content was similar among all Year 1 experimental mixes, the organic $\mathrm{N}$ in the compost was not mineralized as rapidly as the organic $\mathrm{N}$ of the biosolids. Deficiencies of available $\mathrm{N}$ and $\mathrm{P}$ (Fig. 1b; Table 2) observed in BA/compost mixes during Year 1 compelled further investigation of biosolids/fly ash mixtures. Furthermore, the biosolids/FA mixture used as a nutrient rich media component in the Year 14BA+1FA+1SS mix was easily handled and unobjectionable. In an effort to improve nutrient availability, compost inclusion was increased in the experimental control (1 sand : $2 \mathrm{CP}$ ) and $1 \mathrm{BA}+2 \mathrm{CP}$ experimental mixtures, and biosolid and FA inclusions were each increased to $20 \%$ by volume in a $3 \mathrm{BA}+1 \mathrm{FA}+1 \mathrm{SS}$ experimental mixture.

Mowing procedures commenced at $50 \%$ 
Table 3. Biomass of experimental sod measured preceding (Year 2), and immediately following (Years 1 and 2), harvest.

\begin{tabular}{|c|c|c|c|c|}
\hline \multirow{3}{*}{$\begin{array}{l}\text { Experimental growth } \\
\text { media mixes }\end{array}$} & \multicolumn{4}{|c|}{ Year $1^{\mathrm{z}}$} \\
\hline & \multicolumn{3}{|c|}{ Application volume $\left(\mathrm{m}^{3} \cdot \mathrm{ha}^{-1}\right)$} & \multirow[b]{2}{*}{ All volumes avg } \\
\hline & 200 & 300 & 400 & \\
\hline & \multicolumn{4}{|c|}{ 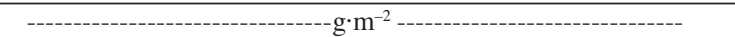 } \\
\hline Control $(2 \text { Sand : } 1 \mathrm{CP})^{\mathrm{y}}$ & 469.8 & 536.6 & 803.6 & $602.4 \mathrm{~b}^{\mathrm{x}}$ \\
\hline $1 \mathrm{BA}+1 \mathrm{CP}$ & 481.7 & 546.1 & 770.3 & $600.0 \mathrm{~b}$ \\
\hline $2 \mathrm{BA}+1 \mathrm{CP}$ & 465.0 & 474.6 & 655.8 & $531.0 \mathrm{~b}$ \\
\hline $4 \mathrm{BA}+1 \mathrm{FA}+1 \mathrm{SS}$ & 627.2 & 727.3 & 882.3 & $745.2 \mathrm{a}$ \\
\hline Avg of all mixes & $510.8 \mathrm{~B}^{\mathrm{w}}$ & $570.5 \mathrm{~B}$ & $777.6 \mathrm{~A}$ & \\
\hline Source of variation & \multicolumn{4}{|c|}{ ANOVA } \\
\hline Mix & \multicolumn{4}{|c|}{$* *$} \\
\hline Volume & \multicolumn{4}{|c|}{$*$} \\
\hline Mix $\times$ volume & \multicolumn{4}{|c|}{ NS } \\
\hline & \multicolumn{4}{|c|}{ Year 2} \\
\hline \multirow[t]{2}{*}{ Experimental growth media mixes } & & 84 DAP & \multicolumn{2}{|r|}{114 DAP } \\
\hline & \multicolumn{4}{|c|}{---------------------- g·m $\mathrm{m}^{-2}$------------------- } \\
\hline Control (1 Sand : 2CP) & & $488.1 \mathrm{abB}$ & & $692.9 \mathrm{~A}$ \\
\hline $1 \mathrm{BA}+2 \mathrm{CP}$ & & $369.0 \mathrm{bB}$ & & $645.2 \mathrm{~A}$ \\
\hline $3 \mathrm{BA}+1 \mathrm{FA}+1 \mathrm{SS}$ & & $621.4 \mathrm{a}$ & & 578.6 \\
\hline $4 \mathrm{BA}+1 \mathrm{FA}+1 \mathrm{SS}$ & & $573.8 \mathrm{a}$ & & 685.7 \\
\hline $2 \mathrm{BA}+1 \mathrm{FA}+1 \mathrm{SS}+1 \mathrm{CP}$ & & $511.9 \mathrm{ab}$ & & 661.9 \\
\hline Purchased sod & \multicolumn{4}{|c|}{$726.2^{v}$} \\
\hline Source of variation & \multicolumn{4}{|c|}{ ANOVA } \\
\hline Mix & \multicolumn{4}{|c|}{$*$} \\
\hline DAP & \multicolumn{4}{|c|}{$*$} \\
\hline Mix $\times$ DAP & \multicolumn{4}{|c|}{$* *$} \\
\hline
\end{tabular}

${ }^{2}$ Sod biomass was measured $99 \mathrm{~d}$ after planting (DAP) in Year 1 experimentation.

${ }^{\mathrm{y}} \mathrm{BA}=$ bottom ash; $\mathrm{CP}=$ municipal compost; $\mathrm{FA}=$ fly ash; $\mathrm{SS}=$ anaerobic-digested sewage sludge.

${ }^{x}$ Within columns, means followed by a different lowercase letter denotes significant difference by mix type, according to Tukey's Studentized range $(\alpha=0.05)$.

"Within rows, means followed by a different uppercase letter denotes significant difference by application volume (Year 1) or DAP (Year 2), according to Tukey's Studentized Range ( $\alpha=0.05$ ).

Ns, ***,****Nonsignificant or significant at $P \leq 0.05,0.01$, and 0.001 , respectively.

Table 4. Physicochemical properties of growth media immediately following harvest, by mixture type and year.

\begin{tabular}{|c|c|c|c|c|c|c|c|}
\hline $\begin{array}{l}\text { Experimental } \\
\text { growth } \\
\text { media mixes }\end{array}$ & $\begin{array}{c}\text { Bulk } \\
\text { density } \\
\left(\mathrm{g} \cdot \mathrm{cm}^{-3}\right)\end{array}$ & $\begin{array}{c}\text { PAW }^{y} \\
\left(\mathrm{~cm}^{-} \mathrm{cm}^{-3}\right)\end{array}$ & $\begin{array}{l}\text { Organic } \\
\text { matter } \\
\left(\mathrm{g} \cdot \mathrm{kg}^{-1}\right)\end{array}$ & $\begin{array}{c}\mathrm{pH}_{\mathrm{H}_{2} \mathrm{O}} \\
(1: 2)\end{array}$ & $\begin{array}{c}\mathrm{pH}_{\mathrm{CaCl}_{2}} \\
(1: 2)\end{array}$ & $\begin{array}{l}\text { Electrical } \\
\text { conductivity } \\
\left(\mathrm{dS} \cdot \mathrm{m}^{-1}\right)\end{array}$ & $\begin{array}{c}\text { Remaining } \\
\text { total N } \\
\left(\mathrm{kg} \cdot \mathrm{ha}^{-1}\right)\end{array}$ \\
\hline Control (2 Sand : 1CP) $)^{v}$ & $1.51 \mathrm{a}^{\mathrm{u}}$ & $0.06 \mathrm{~d}$ & $\begin{array}{l}\text { Year } 1 \\
21.0 \mathrm{c}\end{array}$ & $5.95 \mathrm{~b}$ & $5.07 \mathrm{~b}$ & $0.10 \mathrm{c}$ & 230 \\
\hline $1 \mathrm{BA}+1 \mathrm{CP}$ & $0.77 \mathrm{~d}$ & $0.14 \mathrm{~b}$ & $111.8 \mathrm{a}$ & $5.82 \mathrm{~b}$ & $5.06 \mathrm{~b}$ & $0.26 \mathrm{a}$ & 493 \\
\hline $2 \mathrm{BA}+1 \mathrm{CP}$ & $0.88 \mathrm{c}$ & $0.10 \mathrm{c}$ & $65.6 \mathrm{~b}$ & $5.94 \mathrm{~b}$ & $5.09 \mathrm{~b}$ & $0.15 \mathrm{~b}$ & 354 \\
\hline $4 \mathrm{BA}+1 \mathrm{FA}+1 \mathrm{SS}$ & $1.04 \mathrm{~b}$ & $0.22 \mathrm{a}$ & $61.6 \mathrm{~b}$ & $7.06 \mathrm{a}$ & $6.37 \mathrm{a}$ & $0.17 \mathrm{~b}$ & 312 \\
\hline $\operatorname{LSD}(\alpha=0.05)$ & 0.08 & 0.03 & 35.9 & 0.30 & 0.15 & 0.05 & --- \\
\hline Source of variation & & & ANOVA & & & & \\
\hline$\overline{\mathrm{Mix}}$ & $* *$ & * & $* * *$ & $*$ & $*$ & * & $\mathrm{nd}^{\mathrm{t}}$ \\
\hline Control (1 Sand : 2CP) & $1.12 \mathrm{a}$ & $0.07 \mathrm{c}$ & $\begin{array}{r}\text { Year } 2 \\
61.4 \mathrm{c}\end{array}$ & $6.03 \mathrm{~b}$ & $5.27 \mathrm{~b}$ & 0.18 & 298 \\
\hline $1 \mathrm{BA}+2 \mathrm{CP}$ & $0.76 \mathrm{~d}$ & $0.08 \mathrm{c}$ & $118.9 \mathrm{a}$ & $6.11 \mathrm{~b}$ & $5.49 \mathrm{ab}$ & 0.26 & 379 \\
\hline $3 \mathrm{BA}+1 \mathrm{FA}+1 \mathrm{SS}$ & $0.98 \mathrm{~b}$ & $0.14 \mathrm{~b}$ & $102.7 \mathrm{ab}$ & $5.96 \mathrm{~b}$ & $5.22 \mathrm{~b}$ & 0.30 & 269 \\
\hline $4 \mathrm{BA}+1 \mathrm{FA}+1 \mathrm{SS}$ & $0.93 \mathrm{~b}$ & $0.13 \mathrm{~b}$ & $87.3 \mathrm{~b}$ & $6.22 \mathrm{ab}$ & $5.64 \mathrm{ab}$ & 0.21 & 301 \\
\hline $2 \mathrm{BA}+1 \mathrm{FA}+1 \mathrm{SS}+1 \mathrm{CP}$ & $0.83 \mathrm{c}$ & $0.17 \mathrm{a}$ & $123.8 \mathrm{a}$ & $5.95 \mathrm{~b}$ & $5.25 \mathrm{~b}$ & 0.34 & 470 \\
\hline Purchased sod & $1.11 \mathrm{a}$ & $0.10 \mathrm{c}$ & $19.4 \mathrm{~d}$ & $6.60 \mathrm{a}$ & $5.81 \mathrm{ab}$ & 0.20 & 115 \\
\hline $\operatorname{LSD}(\alpha=0.05)$ & 0.097 & 0.05 & 24.8 & 0.48 & 0.33 & --- & --- \\
\hline Source of variation & & & ANOVA & & & & \\
\hline
\end{tabular}

${ }^{2}$ Experimental growth media were mixed on a volume basis.

${ }^{\mathrm{P}} \mathrm{PAW}=$ volumetric plant available water released between 10 and $1450 \mathrm{kPa}$.

${ }^{\mathrm{x}}$ Organic matter measured by loss on ignition $\left(440^{\circ} \mathrm{C}\right)$.

"Remaining total $\mathrm{N}$ is calculated on the basis of $2 \mathrm{~cm}$ of growth media attached per unit area sod.

${ }^{ } \mathrm{BA}=$ bottom ash $; \mathrm{CP}=$ municipal compost; $\mathrm{FA}=$ fly ash; $\mathrm{SS}=$ anaerobic-digested sewage sludge.

"Within columns, means followed by a different lowercase letter denotes significant differences by mix, according to Tukey's Studentized Range.

'nd = not determined.

Ns,,$* * * * * *$ Nonsignificant or significant at $P \leq 0.05,0.01$, and 0.001 , respectively. vegetative coverage in Year 2. This start date was 58 DAP, $22 \mathrm{~d}$ after the start of mowing in the first year of the study. This may have resulted from the earlier sprigging date and cooler early summer temperatures experienced in Year 2. Average maximum air temperature for the months of June and July were both 33 ${ }^{\circ} \mathrm{C}$ in 2000 , but only 29 and $31^{\circ} \mathrm{C}$, respectively, in 2001 (data not shown). Cassman and Munns (1980) showed mineralization rate of soil organic $\mathrm{N}$ to be directly related to temperature increase in this range.

Nitrogen sufficiency ( $\mathrm{N}$ concentration $>37 \mathrm{~g} \cdot \mathrm{kg}^{-1}$ tissue) was observed for every replication of mixes containing biosolids throughout the entire season. Mixes without biosolids (the control and 1BA $+2 \mathrm{CP}$ mixes) possessed $\mathrm{N}$ concentrations below $90 \%$ of the other mixes and required 1 and 2 supplemental fertilizations ( $\mathrm{N}$ at $24.5 \mathrm{~kg} \cdot \mathrm{ha}^{-1}$ ), respectively (Fig. 1b). These differences in $\mathrm{N}$ requirements compared to Year 1 results are likely due to the greater organic $\mathrm{N}$ content of the Year 2 mixes. On the basis of measured $\mathrm{N}$ content in the leaf clippings throughout the propagation period, the biosolid/FA component appeared to provide mineralized $\mathrm{N}$ more rapidly than the compost.

Total plant essential nutrient levels in leaf tissue varied by mix type and date or both interactively (Table 2). Nitrogen and P content in leaf tissue of bermudagrass grown on media containing biosolid/FA was significantly greater than the control and $\mathrm{BA} /$ compost growth media types at $67 \mathrm{DAP}$. Leaf content of the measured secondary macronutrients varied by DAP (Table 2). Calcium levels remained constant from 67 to 85 DAP in all the media types but decreased significantly from 85 to $115 \mathrm{DAP}$ in the $1 \mathrm{BA}+2 \mathrm{CP}$ and $3 \mathrm{BA}+1 \mathrm{FA}+1 \mathrm{SS}$ mixtures. Magnesium levels varied by mix and were lowest in the $1 \mathrm{BA}+2 \mathrm{CP}$ media, even though all growth media mixtures possessed near equivalent total $\mathrm{Mg}$. For all growth media types, magnesium levels increased equally throughout the course of the experiment. Although several differences in nutrient concentration were observed, all sod was successfully harvested at 114 DAP, $33 \%$ to $66 \%$ of the time normally required for bermudagrass sod maturation in traditional sod production systems (McCarty et al., 1999).

Year 2 postharvest. As in Year 1, physicochemical characteristics of growth media were favorable for plant growth as illustrated by $\mathrm{pH}$ and EC at experiment start and finish (Tables 1 and 4, respectively). Mixture composition significantly affected turfgrass biomass production, but only at $84 \mathrm{DAP}$. Sod grown on the $3 \mathrm{BA}+1 \mathrm{FA}+1 \mathrm{SS}$ and $4 \mathrm{BA}+1 \mathrm{FA}+1 \mathrm{SS}$ mixtures possessed $55 \%$ to $68 \%$ greater biomass than the $1 \mathrm{BA}+2 \mathrm{CP}$ mixture after 12 weeks (Table $3)$. At 114 DAP there were no significant differences in biomass by mix-types. Although a mix type $\times$ harvest date interaction was observed, sod biomass of the $3 \mathrm{BA}+1 \mathrm{FA}+1 \mathrm{SS}$, $4 \mathrm{BA}+1 \mathrm{FA}+1 \mathrm{SS}$, and $2 \mathrm{BA}+1 \mathrm{FA}+1 \mathrm{SS}+1 \mathrm{CP}$ mixtures did not significantly improve following $84 \mathrm{~d}$ of maturation. These mixes containing FA and SS could have been harvested as early as 84 DAP. Sod produced on these growth 
media fostered production of biomass similar to the retail sod (Table 3).

In Year 2, measured bulk density and PAW $_{\mathrm{v}}$ levels significantly varied by growth media type. All FA-containing media $(3 \mathrm{BA}+1 \mathrm{FA}+1 \mathrm{SS}, 4 \mathrm{BA}+1 \mathrm{FA}+1 \mathrm{SS}$, and $2 \mathrm{BA}+1 \mathrm{FA}+1 \mathrm{SS}+1 \mathrm{CP})$ retained significantly greater volumetric water than the commercially produced $1 \mathrm{BA}+2 \mathrm{CP}$, and control sod (Table 4).

Wear/compaction treatments were applied to the sod 2 months following installation in Year 2. In Apr. 2002, significant differences in rooting strength were observed by compaction treatment but not by mix-type or mix-type $x$ compaction treatment (data not shown). Visual quality of the installed sod was affected by compaction treatment and mix type, interactively. In the wear-treated plots, the commercially produced sod had significantly greater visual quality than the $3 \mathrm{BA}+1 \mathrm{FA}+1 \mathrm{SS}, 4 \mathrm{BA}+1 \mathrm{FA}+1 \mathrm{SS}$, and $2 \mathrm{BA}+1 \mathrm{FA}+1 \mathrm{SS}+1 \mathrm{CP}$ mixes. Conversely, all $\mathrm{CCB}$ and control sod not subjected to wear possessed significantly greater visual quality than their compacted counterparts, as well as the no-wear commercially grown sod (data not shown). Bermudagrass sod grown on $\mathrm{CCB}$ growth mixes may not be suitable for locations where high-compaction/wear activities occur.

Environmental risk. All experimental growth media were considered exceptional quality sludges under U.S. Environmental Protection Agency (USEPA) regulations and thus, unrestricted for horticultural or land applications not exceeding agronomic requirements (USEPA, 1993). The biosolids utilized in both years were classified as "Class B" under indicator organism density limits (USEPA, 1993). Part 503 of federal regulation requires Class-B biosolid to undergo vector attraction reduction alternatives and/or "processes to further reduce pathogens (PFRP)." In our study, biosolids were anaerobically digested and de-watered as a processing vector attraction reduction alternative prior to mixing with CCB. Incorporation of the material into the soil within $6 \mathrm{~h}$ of application qualifies as a physical barrier vector attraction reduction alternative. The most effective method of ensuring environmental quality begins with proper site selection. The described method is not recommended for sandy soils and/or soils having high water tables. The ideal site for the described method would possess a clayey soil type with $<2 \%$ slope. Utilization of a ClassA biosolid at rates not exceeding agronomic requirements could be conducted without any regulatory monitoring or PFRP.

Technical considerations. Plant available water in sod is highly desirable. Available water in soil can prolong sod viability under highevapotranspiration conditions. In this study, growth media comprised of CCB retained greater amounts of plant available water than the soil of the retail sod (Table 4). Shipping costs are directly related to the weight of finished sod. Commercially produced sod ranges in weight from 900 to $1700 \mathrm{~kg}$ per pallet $\left(51 \mathrm{~m}^{2}\right)$ (McCarty et al., 1999). All CCB-grown sod in our trials weighed-in at the lower end of this

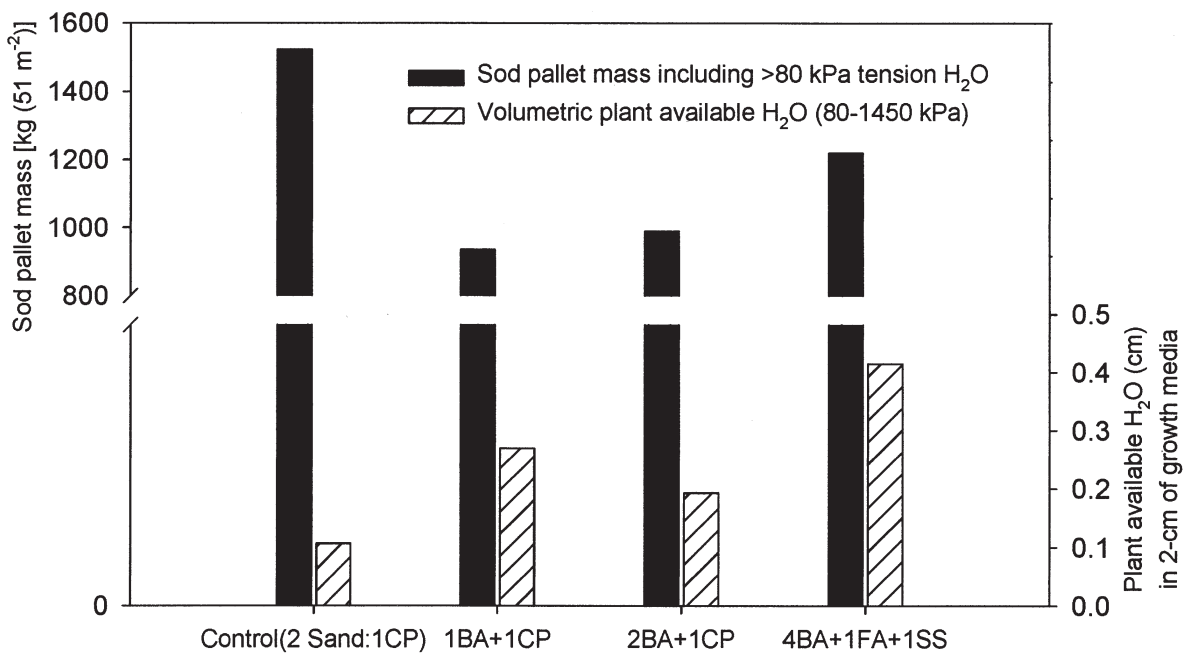

Fig. 2. Postharvest total pallet mass (growth media + sod biomass $+>80 \mathrm{kPa}$ tension gravimetric $\mathrm{H}_{2} \mathrm{O}$ ), and corresponding volumetric $\mathrm{H}_{2} \mathrm{O}(80-1450 \mathrm{kPa})$ of Year 1 bermudagrass sod. Values based on $2 \mathrm{~cm}$ of growth media included in sod product. Growth media were comprised of bottom ash (BA), fly ash (FA), anaerobic digested biosolids (SS), and/or municipal compost (CP) in the volumetric ratios indicated.

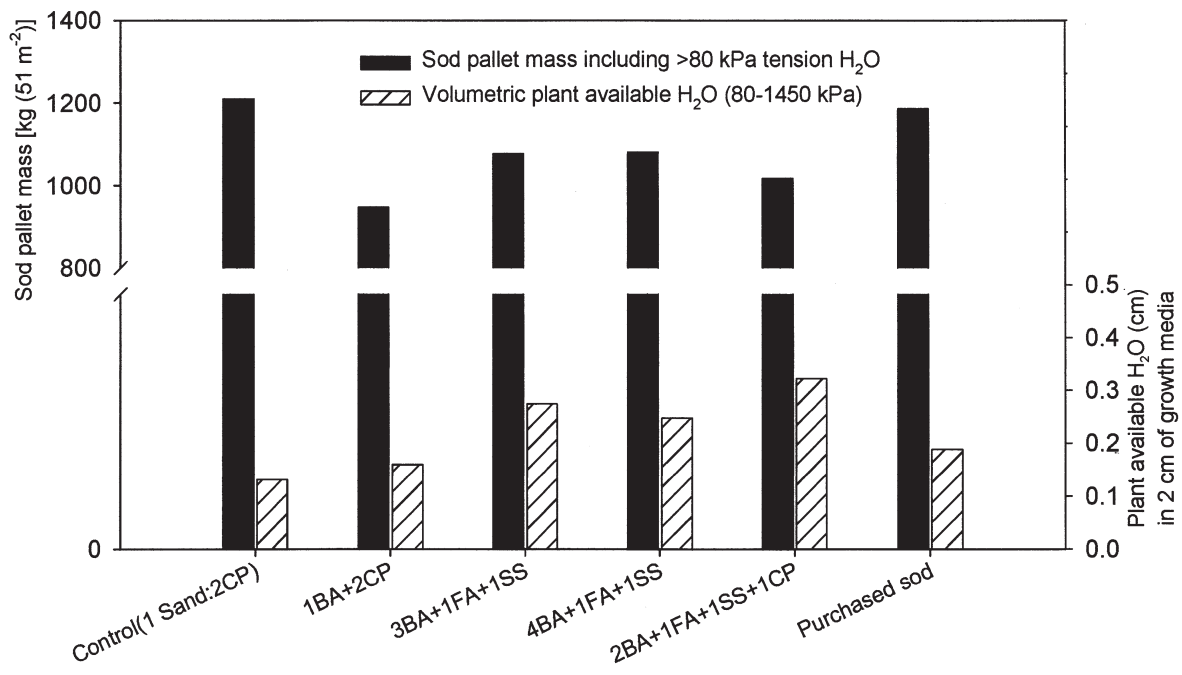

Fig. 3. Postharvest total pallet mass (growth media + sod biomass $+>80 \mathrm{kPa}$ tension gravimetric $\mathrm{H}_{2} \mathrm{O}$ ), and corresponding volumetric $\mathrm{H}_{2} \mathrm{O}(80-1450 \mathrm{kPa})$ of Year 2 bermudagrass sod. Values based on $2 \mathrm{~cm}$ of growth media included in sod product. Growth media were comprised of bottom ash (BA), fly ash (FA), anaerobic digested biosolids (SS), and/or municipal compost (CP) in the volumetric ratios indicated.

range (Figs. 2 and 3). Even with more plant available water retained, the pallet weight of all CCB-grown sod was $9 \%$ to $20 \%$ less than the commercially produced sod. This clear benefit should be realized by the agents of sod delivery (often sod producers), sod wholesalers, retailers responsible for irrigating unsold sod pallets in storage, and installers of the sod.

Remaining reserves of soil organic $\mathrm{N}$ within growth media could be considered an added value of the sod. If harvested to include $2-\mathrm{cm}$ of growth media, installation of the Year 1 control (2 Sand : 1CP), IBA+1CP, 2BA+1CP, and $4 \mathrm{BA}+1 \mathrm{FA}+1 \mathrm{SS}$ sod would concomitantly include $\mathrm{N}$ at $230,493,354$, and $312 \mathrm{~kg} \cdot \mathrm{ha}^{-1}$, respectively. Similarly, Year 2 produced control (1 Sand : 2CP), 1BA+2CP, 3BA+1FA+1SS, $4 \mathrm{BA}+1 \mathrm{FA}+1 \mathrm{SS}$, and $2 \mathrm{BA}+1 \mathrm{FA}+1 \mathrm{SS}+1 \mathrm{CP}$ sod would concomitantly include $\mathrm{N}$ at 298 , $378,269,301$, and $470 \mathrm{~kg} \cdot \mathrm{ha}^{-1}$, respectively
(Table 4). These $\mathrm{N}$ levels remaining in the growth media after sod harvest are variably available but would likely minimize fertilization requirements following installation. The purchased sod possessed $\mathrm{N}$ at only $115 \mathrm{~kg} \cdot \mathrm{ha}^{-1}$ at installation (Table 4). The inherently low $\mathrm{N}$ level of the commercially produced 'TifSport' sod likely contributed to its significantly poorer green up under non-compacted conditions in Spring 2002.

Implementing $\mathrm{CCB}$ and biosolids together as growth media in sod production appears to be an agronomically and economically sound method of managing societal waste. Soil and plant materials associated with our experimental production possessed trace element concentrations below regulated levels (data not shown). Land application of bottom ash, fly ash, and organic wastes/products is an effective method of producing bermudagrass 
sod. Application of the described biosolids/FA mixtures (dry weight) resulted in applications of FA at $\approx 65 \mathrm{Mg} \cdot \mathrm{ha}^{-1}$. Bottom ash utilization ranged from 140 to $280 \mathrm{Mg} \cdot$ ha $^{-1}$ (dry weight). For sod producers interested in implementing this method, the authors recommend contacting an environmental consulting group in their state, ideally a firm with experience in land-application systems.

\section{Literature Cited}

Adriano, D.C. and J.T. Weber. 2001. Influence of fly ash on soil physical properties and turfgrass establishment. J. Environ. Qual. 30:596-601.

Bearce, B.C., S. Myers, M. Burch, B. Engstrom, and L. Smutna. 1997. Proc. Intl. Symp. Coal Combustion By-product (CCB) Mgt. Use 1:4-1.

Ben-Dor, E. and A. Banin. 1989. Determination of organic matter content in arid-zone soils using a simple "loss-on-ignition" method. Commun. Soil Sci. Plant Anal. 20:1675-1695.

Breslin, V.T. 1995. Use of MSW compost in commercial sod production. BioCycle 15(5):68-72.

Butler, S.H. and B.C. Bearce. 1995. Greenhouse rose production in media containing coal bottom ash. J. Environ. Hort. 13:160-164.

Campbell, D.J., W.E. Fox, R.L. Aitken, and L.C. Bell. 1983. Physical characteristics of sands amended with fly ash. Aust. J. Soil Res. $21: 147-158$.

Carrow, R.N., D.V. Waddington, and P.E. Rieke. 2001a. Turfgrass soil fertility and chemical problems: Assessment and management, Ann Arbor Press, Chelsea, Mich.

Carrow, R.N., R.R. Duncan, J.E. Worley, and R.C. Shearman. 2001b. Turfgrass traffic (soil compaction plus wear) simulator: Response of Paspalum vaginatum and Cynodon spp. Intl. Turf. Soc. Res. J. 9:253-258.

Cassman, K.G. and D.N. Munns. 1980. Nitrogen mineralization as affected by soil moisture, temperature, and depth. Soil Sci. Soc. Amer. J. 44:1233-1237.

Castellanos, J.Z. and P.F. Pratt. 1981. Mineralization of manure nitrogen-Correlation with laboratory indexes. Soil Sci. Soc. Amer. J. 45:354-357.
Cisar, J.L. and G.H. Snyder. 1992. Sod production on a solid-waste compost over plastic. HortScience 27:219-222.

Hanna, W.W., R.N. Carrow, and A.J. Powell. 1997. Registration of 'Tift 94' bermudagrass. Crop Sci. 37:1012.

Haydu, J.J. and J.L. Cisar. 1993. Sales, quality, and market channel characteristics of Florida sod, $p$. 1-4. In: Turf dollars and sense. Univ. of Florida Coop. Ext. Serv. Food and Resour. Econ. Dept., vol. 5 , no. 3 .

Jones, J.B., Jr. 1991. Plant tissue analysis in micronutrients, p. 477-521. In: J.J. Mortvedt et al. (ed.). Micronutrients in agriculture. Soil Sci. Soc. Amer. Book Ser. No. 4 (2nd ed), Madison, Wis.

King, J.W. and J.B. Beard. 1969. Measuring rooting of sodded turfs. Agron. J. 61:497-498.

Klute,A. 1986. Water retention: Laboratory methods, p. 635-662. In: A. Klute (ed.). Methods of soil analysis. Part 1. Physical and mineralogical methods. Agron. Monogr. No. 9, (2nd ed.). Amer. Soc. Agron. and Soil Sci. Soc. Amer., Madison, Wis.

McCarty, B., G. Landry, Jr., J. Higgins, and L. Miller. 1999. Sod production in the southern United States. Clemson Univ. Coop. Ext. Serv. Bul. EC702.

Miller, D.M., W.P. Miller, S. Dudka, and M.E. Sumner. 2000. Characterization of industrial by products, p. 107-126. In: J.F. Power and W.A. Dick (ed.). Land application of agricultural, industrial, and municipal by-products. Soil Sci. Soc. Amer. Spec. Publ. 6, Madison, Wis.

Nelson, D.W. and L.E. Sommers. 1996. Total carbon, organic carbon and organic matter, p. 961-1010. In: D.L. Sparks (ed.). Methods of soil analysis. Part 3. Chemical methods. Amer. Soc. Agron. and Soil Sci. Soc. Amer., Madison, Wis.

Okuda, K., H. Kondo, and M. Miura. 1997. Utilization of solidified coal ash as a substitute for sand and stone. Proc. Intl. Symp. Coal Combustion By-product (CCB) Mgt. Use 2:55-1-17.

Pathan, S.M., L.A.G. Aylmore, and T.D. Colmer. 2001. Fly ash amendment of sandy soil to improve water and nutrient use efficiency in turf culture. Intl. Turf. Soc. Res. J. 9:33-39.
Rhoades, J.D. 1996. Salinity: Electrical conductivity and total dissolved solids, p. 417-435. In: D.L. Sparks (ed.). Methods of soil analysis. Part 3. Chemical methods - Soil Sci. Soc. Amer. Book Ser. No. 5, Madison, Wis.

Ruemmele, B.A., M.C. Engelke, R.H. White, and V. Lehman. 2001. Alternative sod production method for zoysiagrass. Intl. Turf. Soc. Res. J. 9:910-916.

Sajwan, K.S., W.H. Ornes, and T.J. Youngblood. 1995. The effect of fly ash/sewage sludge mixtures and application rates on biomass production. J. Environ. Sci. Health. 30:1327-1337.

Schlossberg, M.J., C.P. Vanags, and W.P. Miller. 2004. Bermudagrass sod growth and metal uptake in coal combustion by-product-amended media. J. Environ. Qual. 33:740-748.

Schumann, A.W. and M.E. Sumner. 1999. Plant nutrient availability from mixtures of fly ashes and biosolids. J. Environ. Qual. 28:1651-1657.

Sikora, L.J. and N.K. Enkiri. 1999. Growth of tall fescue in compost/fertilizer blends. Soil Sci. 164:62-69.

Sloan, J.J. and D. Cawthon. 2001. Mine soil remediation using coal ash and compost mixtures. Proc. VIIntl. Conf. Biogeochem. Trace Elements (ICBOTE) 6:380.

Tester, C.F. 1990. Organic amendment effects on physical and chemical properties of a sandy soil. Soil Sci. Soc. Amer. J. 54:827-831.

Thomas, G.W. 1996. Soil pH and soil acidity. p. 475-490. In: D.L. Sparks (ed.). Methods of soil analysis. Part 3. Chemical methods. Book Ser. No. 5 Amer. Soc. Agron. and Soil Sci. Soc. Amer., Madison, Wis.

U.S. Environmental Protection Agency. 1993. 40 CFR Parts 257, 403, and 503. Fed. Reg., 58:9248-9415.

Wagner, D.F. and J.C. Neal. 1984. Coal cinders with pine bark as azalea growing media. J. Amer. Soc. Hort. Sci. 109:822-826.

Wong, J.W.C. 1995. The production of artificial soil mix from coal fly ash and sewage sludge. Environ. Tech. 16:741-751.

Woodard, M.A., B.C. Bearce, S. Cluskey, and E.C. Townsend. 1993. Coal bottom ash and pinewood peelings as root substrates in a circulating nutriculture system. HortScience 28:636-638. 